\title{
A theoretical contribution from the perspective of sustainability in hospitality marketing management
}

\author{
Bruno Sousa, PhD \\ IPCA - Polytechnic Institute of Cávado and Ave / ISAG - European Business School / University of Minho, Portugal
}

\begin{abstract}
The innovation process, and its application to tourism, has been gradually gaining ground in the academic community as a field of study. Similarly, in recent decades, tourism has received greater attention from researchers in various sciences, varying only by the different emphases considered: economic, social, cultural and environmental. This study seeks to gather and present the main aspects related to innovation process in specific tourism context, in particular the case of sustainable tourism in hospitality marketing management. Tourism is one of the economic sectors in which a great degree of involvement is needed by the entrepreneurial sector: diversification of tourism products and services is needed to cope with increased demand for new types of tourism needs. As other emerging sectors in a modern economy, tourism is a dynamic and ever-changing industry. The study has as purpose to provide a better understanding regarding the essence of innovation process with sustainability solutions. Regarding the methodology used here, this is a conceptual paper with a literature review that brings together the major components of innovation process in sustainable tourism.
\end{abstract}

Keywords: Innovation process, process creation, sustainable tourism, ecotourism

\section{Introduction}

According to Ma and Tan (2006, p.705), "there has been an increasingly popular trend of crossfertilization among strategic management research and entrepreneurship research, two fields deeply concerned with wealth creation and heavily influenced by Schumpeter's seminal work on innovation and creative destruction". With regard to its proximity to the concept of innovation, Schumpeter (1934) argues that innovation can be seen as a phenomenon, including technical, non-technical aspects as well as innovations in product and process innovations. The creation process contributes to business success and increased competitive advantage (Sousa \& Lopes, 2012), which is a theme that has clearly captured the attention of researchers in the field of management. The dynamic nature of this process, coupled with the constant need to invest in a highly distinctive and differentiating offering new studies have provided in order to score market position and achieve consumer satisfaction, including the level of emerging realities confirmed by new trends and desires (Costa, 2001; Buhalis \& Costa, 2006). Innovation is the adoption of a change that results in something new to the organization and relevance to the environment, and the creative idea and its development is the seed germinated by innovative, effective for the market economy (Dosi, 1988). In this sense, innovation has attracted the attention of several scholars and entrepreneurs together with entrepreneurship in tourism contexts. In this context, and according to Orams (2005), the concept of ecotourism is probably equally due to the widespread and growing interest in the natural environment and a corresponding recognition of the importance of conserving natural environmental quality. The idea of visiting and experiencing highquality natural environments and also protecting them from harmful impacts is now an acceptable and marketable one.This makes it possible to open new doors and open new markets, enabling greater efficiency in business, economic growth and new ways of targeting an increasingly competitive market (Kastenholz, Davis \& Paul 1999), in specific the sustainable tourism products and services.

\section{Innovation as a source of competitive advantage}

Innovation can be seen as a specific tool of entrepreneurs, the means with which exploit change as an opportunity for a different business or service, being able to be understood and, as such, to be practiced, leading to a common distinction between invention and innovation (Drucker, 1993). Almost all the innovations reflect existing knowledge, combined with new uses, suffering the concept of innovation as a shift towards emphasis on the interaction between institutions, focus on interactive for the creation, dissemination and sharing of knowledge and relevance of the role of government processes as an important actor in an innovative environment. 
It is important to clarify the difference between two concepts that, for different times, tend to be confused: Process Innovation and the Innovation Process. Innovation Process is essentially related to the set of steps that tend to incorporate both the market and technology. Companies have the ability to go seizing, building your knowledge base and thus make the continuous improvement of process management (Tidd, Bessant \& Pavitt, 2003). Monitor the internal and external environment and analyze the relevant signals will be the starting point. After this, we have the decision about how to respond. Finally, we will implement the project with the development of technology and the domestic and foreign market.

The Process Innovation, by the way, combines the adoption of a process view of the organization's business with the application of innovation to key processes. This is the big difference, compared with the Innovation Process, but it allows us to understand its complexity. Process Innovation encompasses the prediction of new work strategies, the actual process activity and the implementation of change in their complex human, technological and organizational dimensions (Davenport, 1993).

According to Davenport (1993), in practice, companies need to combine the two concepts in a continuous quality program (Figure 1). Ideally, the organization will seek to stabilize the process and start continuous improvement, to later create the ambition to go on the innovation processes. The differences between these two concepts can hinder your combination, so one of the possibilities to minimize this problem may be the assignment of different roles to different managers, with high levels of cooperation. According to the author, the company must be aware that the risk of innovation processes is at least proportional to the rewards for that in reduced competitiveness continuous improvements environments may be the preferred choice. Highly competitive environments (e.g. greater balance between enterprises, reduced rate of market growth, high barriers to exit) may encourage the bet on a change with the greatest impact (process innovation). Access to information and the challenge of the information revolution is also the base of the reach of competitive advantage, in order to maximize innovation in the process and, consequently, greater differentiation from competitors (Porter \& Millar, 1985).

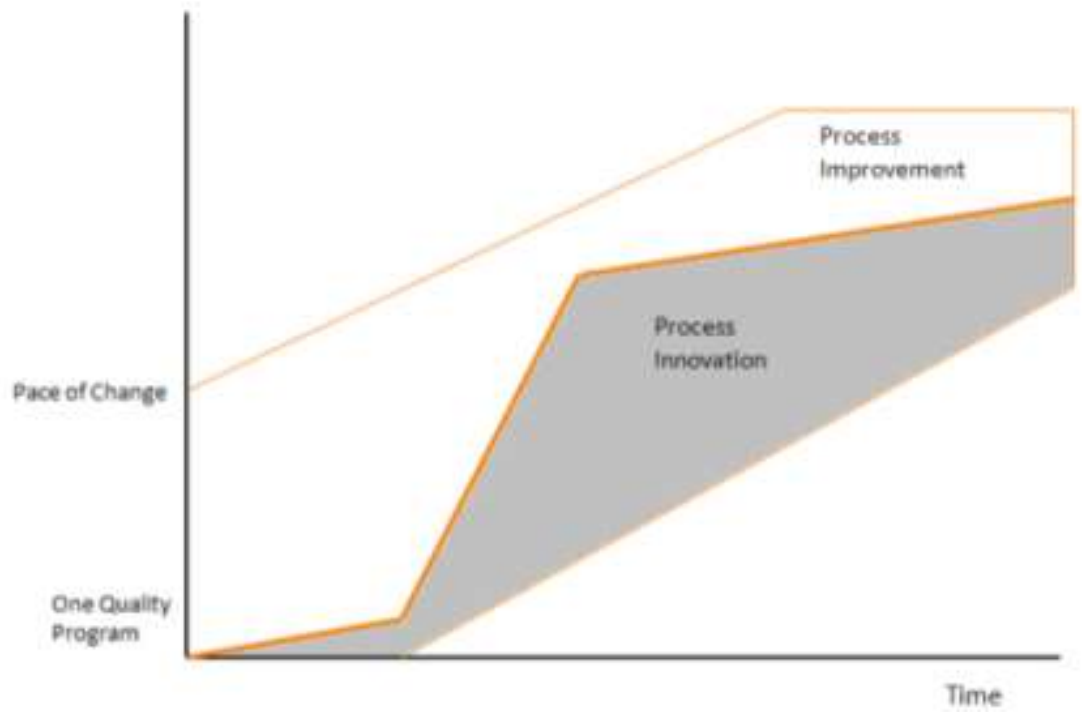

Figure 1: Relationship between Innovation in Product and Process Source: Davenport, 1993

\section{The creation process in sustainable tourism and ecotourism}

Tourism is a phenomenon that moves millions of people around the world, taking as a major driver of the global economy. Every year, much due to the frequent changes in the tourism environment, fosters competition between and within tourist destinations (Bigné \& Andreu, 2004; Farhangmehr \& Simões, 1999). It is multifaceted and geographically complex activity, where different services are ordered and delivered in different stages, from origin to destination (Pearce, 1991). Moreover, tourism is a sector of great importance to the economy, responsible for creating a large number of jobs. For instance, female entrepreneurship in the tourism sector has been rather neglected as a field of study and women's employment opportunities and the segregation of occupations are the major focus of research on women's situation in the tourism context (Costa, Carvalho \& Breda, 2011). As a psychological phenomenon, a tourist trip is preceded by a specific need that generates a reason to travel and sets a goal for the trip, which follows the search for information (Gursoy \& 
McCleary, 2004; Pearce \& String, 1984). Like other emerging sectors in a modern economy, tourism is a dynamic and ever-changing industry (e.g. sustainable tourism). For instance, and according to Orams (2005), the concept of ecotourism is probably equally due to the widespread and growing interest in the natural environment and a corresponding recognition of the importance of conserving natural environmental quality. The idea of visiting and experiencing highquality natural environments and also protecting them from harmful impacts is now an acceptable and marketable one. As a result, a suitable term which evokes the positive images associated with the term 'eco', for example, in ecology, ecosystem, ecosphere and eco-sensitive, with the activity of tourism has been combined to create a name that expresses a concept which has become popular.

Similarly, sustainable tourism development should be seen as an adaptive paradigm, a part of the parental concepts of development and sustainable development, and it should aim at contributing to objectives of sustainable development and development in general by determining specific principles in the light of its parental concepts (Tosun, 2001). According Hassan (2000), therefore, tourism marketing for the new millennium and beyond must focus on forms of tourism that are sensitive to promoting and sustaining the environmental integrity of natural and cultural heritage resources. Negative effects of tourism development and growth on the destination and its environment can decrease its long term comparative advantage and reduce tourist demand. According Hardy, Beeton \& Pearson (2002), the evolution of the concept of 'sustainable tourism' was evident in the literature before the term sustainable development was officially used. An example of this is include Butler's Destination Life Cycle Model (Butler, 1980), which has been argued as reflecting the concept of sustainable development indirectly (Hunter, 1995, 1997) and the concept of carrying capacity (Stankey, 1973).

In summary, an review of the variety of ecotourism or sustainable tourism definitions shows that, at a minimum, ecotourism is tourism which is based on the natural environment and seeks to minimize its negative impact on that environment. However, many definitions argue that ecotourists should attempt to do more than simply minimize impacts. They should also contribute to the health and quality of the natural attractions which they visit. It may be that one of the challenges for the ecotourism industry is to assist in moving ecotourists from a minimal 'passive' position to a more 'active' contribution to the sustainability of 'eco-attractions' (Orams, 2005).

Thus, and an example, a Portuguese innovation in Shanghai 2010 (figure 2) Tourist Transportable Tower (TTT) proved a bet Portuguese company DST at the World Expo, taking as a multifunctional design of sustainable architecture, with 9 meters tall, 3 wide and 3 deep, assuming an autonomous space minimalist design oriented to nature and sustainable tourism. According DST Group, the TTT "is an industrialised project and a multifunctional sustainable architecture. It is, simultaneously, an urban modularity and evolutionary procedure, of environmental integration and touristic mobility, in an innovative mixture that represents a new concept in habitability". With a minimal design and a strong revealing image, bold at the level of the structural solution, TTT combines natural lighting and energetic potential through active and passive solar systems. Its physical dimension and inner space is optimised with resort to the prevalence of a harmonious and integrated relation with the outer surroundings. The present technology establishes an innovative timber-glass composite constructive system in which the combination of these materials simultaneously assumes energetic, structural, functional and aesthetic character. The system materialises through a multipurpose modular panel, able to be applied horizontally - as slab - or vertically - as sustaining wall. It integrates passive solar systems and bioclimatic functions, which results in energetic efficiency, thus constituting a clear innovation in terms of prefabricated structural elements (DST, 2013).

Figure 2 - Tourist Transportable Tower

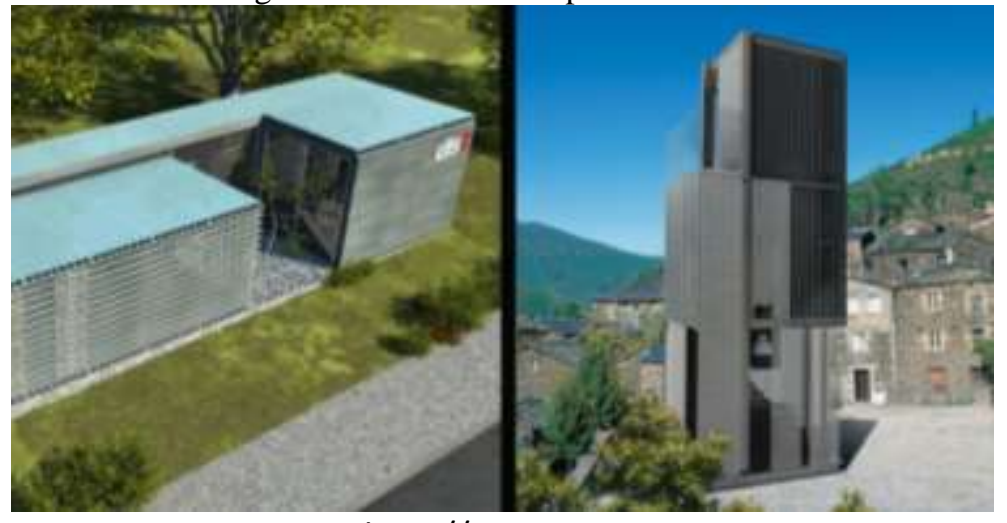

Source: http://www.tttower.com 
Similarly, and according to Stronza (2007), built over the course of two years with a half million dollar investment (from a Peru-Canada bilateral development plan), the ecolodge Posada Amazonas has earned many international awards and publicity for its innovation in linking business with conservation and community development. It was one of the first ecotourism lodges in the world to partner a private tour company with a local community (figure 3). Posada Amazonas offers ample opportunities to see wildlife and experience the Amazon's rich ecosystem at firsthand.

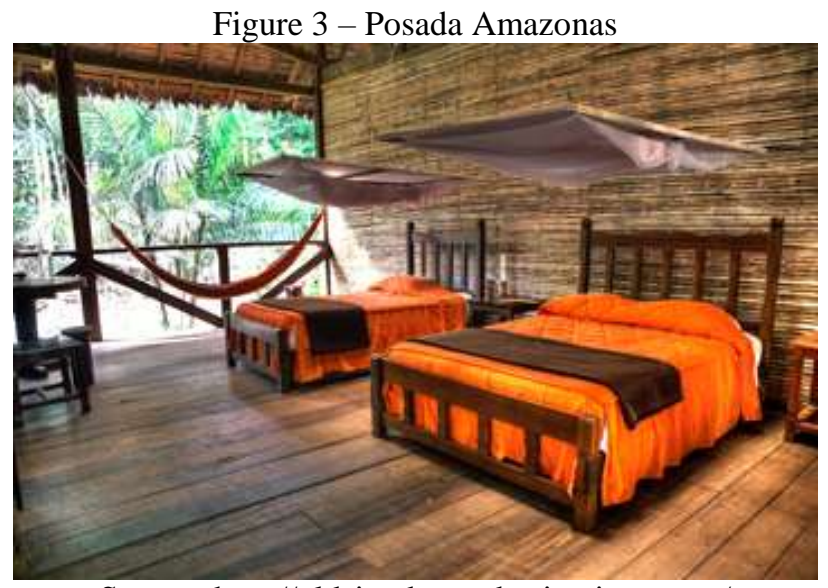

Source: http://oldsite.detourdestinations.com/

Similarly, Ecorkhotel, Évora Suites \& SPA (figure 4) is a superior four-star hotel born of a 7 million euro investment. Comprising 56 private suites, spa, gym, indoor and outdoor pool, restaurant and meeting rooms, the hotel will be marketed primarily to international clients, as an eco-resort. The hotel's exterior is covered with MD Fachada expanded cork agglomerate supplied by Amorim Isolamentos, over a total area of $1200 \mathrm{~m} 2$. The choice of expanded cork agglomerate as the central element of the building's look is in complete harmony with the hotel's setting, a magnificent Alentejo landscape surrounded by cork oak forests. The use of the material will result in a number of exceptional benefits in terms of energy savings, a major asset for a hotel designed with eco-efficiency in mind.

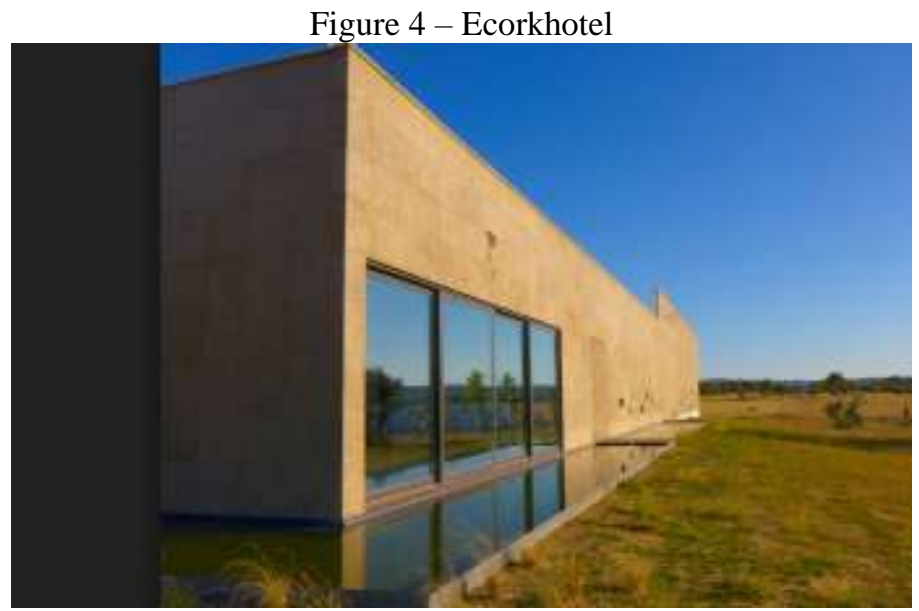

Source: www.ecorkhotel.com

Similarly, Inspira Santa Marta Hotel in Lisbon picked up the award for a wide range of efforts intended to do more than improve hotel performance, but to become - and incentivise others to become - more environmentally responsible. The hotel's core concept is sustainability without compromising the comfort of guests. Inspira implemented measures to minimise its ecological footprint, reducing consumption in all operations areas, using $100 \%$ green energy, thermal accumulators, recycling systems and paperless procedures, amongst other initiatives. The hotel's ambitions aim to respect the environment whilst meeting the demands of its environmentally conscious guests, and the award is recognition for all the programmes in which Inspira has invested over the past four years, and is another step to become a leading example of sustainability. 
The nature and sustainable tourism should be a touristic product that is highly recognized for its potential in the exploration of endogenous regional resources. Consequently, the development of new and competitive tourism products can play an important role in the development of the inland regions, contributing effectively to addressing the economic asymmetries of the region. Similarly, wellness tourism is promoted through various services that are practiced in order to relax and rejuvenate. Hot springs have been one such effective method that has tremendously added to the dimensions of the wellness tourism. Naturally occurring hot springs and the use of their water is highly important in various wellness therapies as well as the procedures that are required to provide rejuvenating experience to the guest. Geothermal energies and hot spring waters are the basis of the wellness therapies like balnoetherapy, thermalism etc. The water of these naturally occurring hot springs usually possesses a very high quantity of mineral content that is used extensively for clinical purposes. Spas and other wellness centers run on the mercy of these waters for these waters are the basis for nearly all the wellness therapies (Jagyasi, 2010). Also in nature and sustainable tourism context, the process of creation and innovation have been increasingly used to describe business behavior, the destinations, the tourism sector as well as all their planning (Dredge, 2009). However, tourism is going through significant changes, facing new challenges that require new perspectives and implementing ideas (Stamboulis \& Skayannis, 2003).

\section{Conclusion and next steps}

In an increasingly global world, which tends to predominate competitiveness and change, the difference is, so often, the ability to create discontinuities in the external environment. Many times the success is the ultimate goal, which focuses on searching for new products, new markets, new organizational forms and new sources of customer value. In this field it inevitably highlights the sustainable tourism as some of the examples mentioned in this paper, as vehicles of innovation, and that may prove suitable choices of context for the operationalization of the proposed study. For instance, the creation process associated with for nature and sustainable reservation systems, mechanisms and information sharing as a form of competitive advantage over other tourist destinations (social networks), the marketing of nature and sustainable tourism products and services as well as other related activities that can leverage the increased business synergies.

The generators entrepreneurship and innovative factors that may trigger an entrepreneurial activity and whose origin may be associated with internal, external factors and characteristics of the organization. In this context, the concept of ecotourism is probably equally due to the widespread and growing interest in the natural environment and a corresponding recognition of the importance of conserving natural environmental quality. It will be interesting to use the methodology of focus groups and exploratory interviews and application questionnaire surveys next to ecotourists and visitors with special interest in nature tourism in order to assess which are the main critical success factors in this sector. It is hoped that the study may represent a starting point for future research for sustainability in tourism and respective innovation of differentiated products and services. This work is primarily theoretical and reflection, thereby is expected to arise in the future some work of a practical nature that bring greater robustness to support and perspectives presented.

\section{References}

[1]. Antunes, V. M. P. (2009). Marketing empreendedor no sector de turismo de saúde e bem-estar (Doctoral dissertation).

[2]. Araujo, A. R., Paiva, T., Ribeiro, M. P., \& Coutinho, P. (2015). Innovation in Thermalism: An Example in Beira Interior Region of Portugal. In Health and Wellness Tourism (pp. 165-180). Springer International Publishing.

[3]. Bigné, J. \& Andreu, L. (2004). Emotions in segmentation - an empirical study, Annals of Tourism Research, 31(3), 682-696.

[4]. Buhalis, D. (2003) eTourism: Information Technology for strategic management, London, Prentice Hall.

[5]. Buhalis D. \& Costa, C. (2006), Tourism Management Dynamics, Trends, Management and Tools, Elsevier Butterworth Heinemann, Oxford, United Kingdom, International Edition.

[6]. Butler, R.W. (1980) The concept of a tourist area cycle of evolution: Implications for management of resources. Canadian Geographer 24(1), 5-12.

[7]. Cole, A. (1959). Business Enterprise in its Social Setting, Harvard University, Press, Boston.

[8]. Costa, C. (2001). An emerging tourism planning paradigm? A comparative analysis between town and tourism planning, International Journal of Tourism Research, 3 (6),425-441.

[9]. Costa, C., Carvalho, I. \& Breda, Z. (2011). Gender inequalities in tourism employment: The Portuguese case. Revista Turismo \& Desenvolvimento, $15,37-52$.

[10]. Costa, C., Quintela, J., \& Mendes, J. (2015). Health and Wellness Tourism: A Strategic Plan for Tourism and Thermalism Valorization of São Pedro do Sul. In Health and Wellness Tourism (pp. 21-31). Springer International Publishing.

[11]. Davenport, T. (1993). Process innovation, reengineering work through information technology. Harvard Business School Press.

[12]. Dosi, G. (1988). Sources, Procedures, and Microeconomic Effects of Innovation. Journal of Economic Literature, 26, 1120-1171.

[13]. Dredge, D. (1999). Destination Place Planning and Design. Annals of Tourism Research, 26(4), $772-791$.

[14]. Drucker, P. (1993). Innovation and Entrepreneurship, Collins, $1^{\mathrm{a}}$ ed.

[15]. Kastenholz, E., Davis, D., \& Paul, G. (1999). Segmenting tourists in rural areas: The case of North and Central Portugal. Journal of Travel Research, 37,3 53-363.

[16]. Farhangmehr, M. \& Simões, C. (1999). Factors Affecting Hotel Industry Development in Portugal. Journal of Hospitality Marketing \& Management, 6(1), 23-46. 


\section{A theoretical contribution from the perspective of sustainability in hospitality marketing management}

[17]. Gartner, W. (1985). A conceptual framework for describing the phenomenon of new venture creation. Academy of management review, 10(4), 696-706.

[18]. Gursoy, D. \& McCleary, K. (2004). An Integrative Model of Tourists' Information Search Behavior, Annals of Tourism Research, 31, 353-373.

[19]. Hardy, A., Beeton, R. J., \& Pearson, L. (2002). Sustainable Tourism: An Overview of the Concept and its Position in Relation to Conceptualisations of Tourism. Journal of Sustaibable Tourism, 10(6), 475.

[20]. Hassan, S. S. (2000). Determinants of Market Competitiveness in an Environmentally Sustainable Tourism Industry. Journal of Travel Research, 38, 239-245.

[21]. Hunter, C. (1995). On the need to re-conceptualise sustainable tourism development. Journal of Sustainable Tourism 3(3), $155-65$.

[22]. Hunter, C.(1997). Sustainable tourism as an adaptive paradigm. Annals of Tourism Research 24(4), 850-67.

[23]. Heilman, M. \& Chen, J. (2003). Entrepreneurship as a solution: the allure of self-employment for women and minorities. Human Resource Management Review, 13(2), 347-364.

[24]. Jagyasi, P. (2010). Medical Tourism: Research \& Survey Report. Dr Prem.

[25]. Kim, W., Lee, C. \& Hiemstra, S. (2004). Effects of an online virtual community on customer loyalty and travel product purchases. Tourism Management, 25 (3), 343-355.

[26]. Lordkipanidze, M.; Brezet, H. \& Backman, M. (2005). The entrepreneurship factor in sustainable tourism development. Journal of Cleaner Production , 13, 787-798

[27]. Luchs, B. (1990). Quality as a strategic weapon. European Business Journal, 2(4), 34-47.

[28]. Ma, H. \& Tan, J. (2006). Key components and implications of entrepreneurship: a 4-P framework. Journal of Business Venturing, 21, 704-725

[29]. Pearce, D. (1991). Tourist Development. Longman Scientific \& Technical, London.

[30]. Pearce, P. L.; Stringer, F. P. (1984), "Toward a symbiosis of social psychology and tourism studies", Annals of Tourism Research, New York;

[31]. Porter, M. (1990). The Competitive Advantage of Nations. Macmillan, New York.

[32]. Porter, M. \& Millar, V. (1985). How information gives you competitive advantage. Harvard Business Review, July-August, 149174.

[33]. Quintela, J. A., Correia, A. G., \& Antunes, J. G. (2011). Service quality in health and wellness tourism-trends in Portugal. International Journal of Business, Management and Social Sciences, 2(3), 1-8.

[34]. Russell, R. \& Faulkner, B. (2004). Entrepreneurship, chaos and the tourism area lifecycle. Annals of Tourism Research, 31(3), 556579 .

[35]. Schumpeter, J. (1934). The Theory of Economic Development. Harvard University Press, Cambridge, Ma.

[36]. Schumpeter, J. (1975). Capitalism, Socialism, and Democracy. Harper and Row, New York. Originally published in 1942.

[37]. Sharma, P. \& Chrisman, J. (1999). Toward a Reconciliation of the Definitional Issues in the Field of Corporate Entrepreneurship. Entrepreneurship Theory and Practice, 23(3), 11-27.

[38]. Sousa, B. \& Lopes, S. (2012). A Inovação de Processos: diferenciação nos Serviços Turísticos, Estudios y Perspectivas en Turismo, volume 21, - número 4 (Julho), 963-976.

[39]. Sousa, B. \& Simões, C. (2012). Uma abordagem na ótica do consumidor: Regiões turísticas transfronteiriças. Journal of Tourism and Development [Revista Turismo \& Desenvolvimento], n. ${ }^{\circ}$ 17/18 - Volume 4, electronic edition, ISSN: 2182-1453.

[40]. Sousa, B. \& Simões, C. (2010). Comportamento e perfil do consumidor de turismo de nichos: o caso de euro-regiões. Revista Tékhne, vol. VIII, $\mathrm{n}^{\circ} 14$.

[41]. Stamboulis, Y. \& Skayannis, P. (2003). Innovation strategies and technology for experience-based tourism. Tourism management, $24,35-43$.

[42]. Stankey, G. (1973) Visitor Perception Wilderness Recreation Carrying Capacity. Utah: USDA Forest Service.

[43]. Stevenson, H. \& Jarillo, J. (1990). A paradigm of entrepreneurship: entrepreneurial management. Strategic Management Journal, 11, 17-27.

[44]. Tidd, J; Bessant, J. \& Pavitt, K. (2003). Gestão da Inovação: Integração das Mudanças Tecnológicas, de Mercado e Organizacionais. Monitor, Lisboa.

[45]. Tosun, C. (2001). Challenges of sustainable tourism development in the developing world: the case of Turkey. Tourism Management, 22(289), 303. 